\title{
THE VEGETATIONAL AND SETTLEMENT HISTORY IN SYSMÄ, CENTRAL SOUTH FINLAND, INTERPRETED ON THE BASIS OF TWO POLLEN DIAGRAMS
}

\author{
IRIELI VUORELA
}

VUORELA, I. 1981: The vegetational and settlement history in Sysmä, central South Finland, interpreted on the basis of two pollen diagrams. Bull. Geol. Soc. Finland 53-1, 47-61.

The Flandrian vegetational history of the parish of Sysmä has been enlightened at two sites by pollen analysis and eight 14-C datings.

Indications of settlement around $6900-5500$ B.P., i.e. at the end of the pre-ceramic Stone Age and the beginning of the ceramic period, are found in pollen data. This is associated with Stone Age settlement in the area of the ancient Lake Päijänne. Also the human activity in the area during the Bronze Age is reflected. The indicators point to a culture based on the grazing of animals, which may be comparable with the Early Metal Age finds elsewhere.

The commencement of permanent settlement may be dated to the Merovingian period $(1270 \pm 130$ and $1360 \pm 120$ radiocarbon years B.P. respectively). This is supported by existing archaeological finds and confirms earlier theories on the origins and direction of migration of this agricultural population.

Irmeli Vuorela, Department of Geology, Division of Palaeontology, University of Helsinki, Snellmaninkatu 5, SF-00170 Helsinki 17, Finland.

\section{Introduction}

Since the early work done on the history of the natural environment of the PäijätHäme region of Finland in the first half of the present century (Tolvanen 1922, L. Aario 1936), the status of the ancient Lake Päijänne, the, 'Päijänne transgression' and the associated discharge of the river Kymijoki at around 6100 B.P. (4150 B.C), have proved topics of interest for both geologists (R. Aario 1965, Saarnisto $1971 \mathrm{a}, \mathrm{b}$ ), and archaelogists, as the date in question marks the borderline between the Early Ceramic and Combedware cultures. It has proved possible to date the phases of the Combed-ware by reference to the location of Stone-Age dwelling sites, mainly to the north of the lake itself (Siiriäinen 1969, 1970, 1973, Eronen and Matiskai- nen 1979), but the means of livelihood of the inhabitants during that period is a problem that remains at least in part unsolved.

The pollen analytical investigations from two lakes reported here are aimed at outlining the settlement history of the PäijätHäme region as represented in the parish of Sysmä. The lake Kaakotinlampi near the village of Nuoramoinen $\left(61^{\circ} 25^{\prime} \mathrm{N} 25^{\circ} 52^{\prime} \mathrm{E}\right)$ is in effect a mire pool (104 $\mathrm{m}$ a.s.1.) enclosed by forest and with no cultivated fields or settlement in its immediate vicinity nowadays, while the lake of Taruslampi in the village of Voipala $\left(61^{\circ} 29^{\prime} \mathrm{N} 25^{\circ} 38^{\prime} \mathrm{E}\right.$, height approx. $81 \mathrm{~m}$ a.s.l.) is located within range of human settlement and is surrounded by agricultural land. The two sites differ in the nature of the lake sediment and rate of sedimentation, and the 


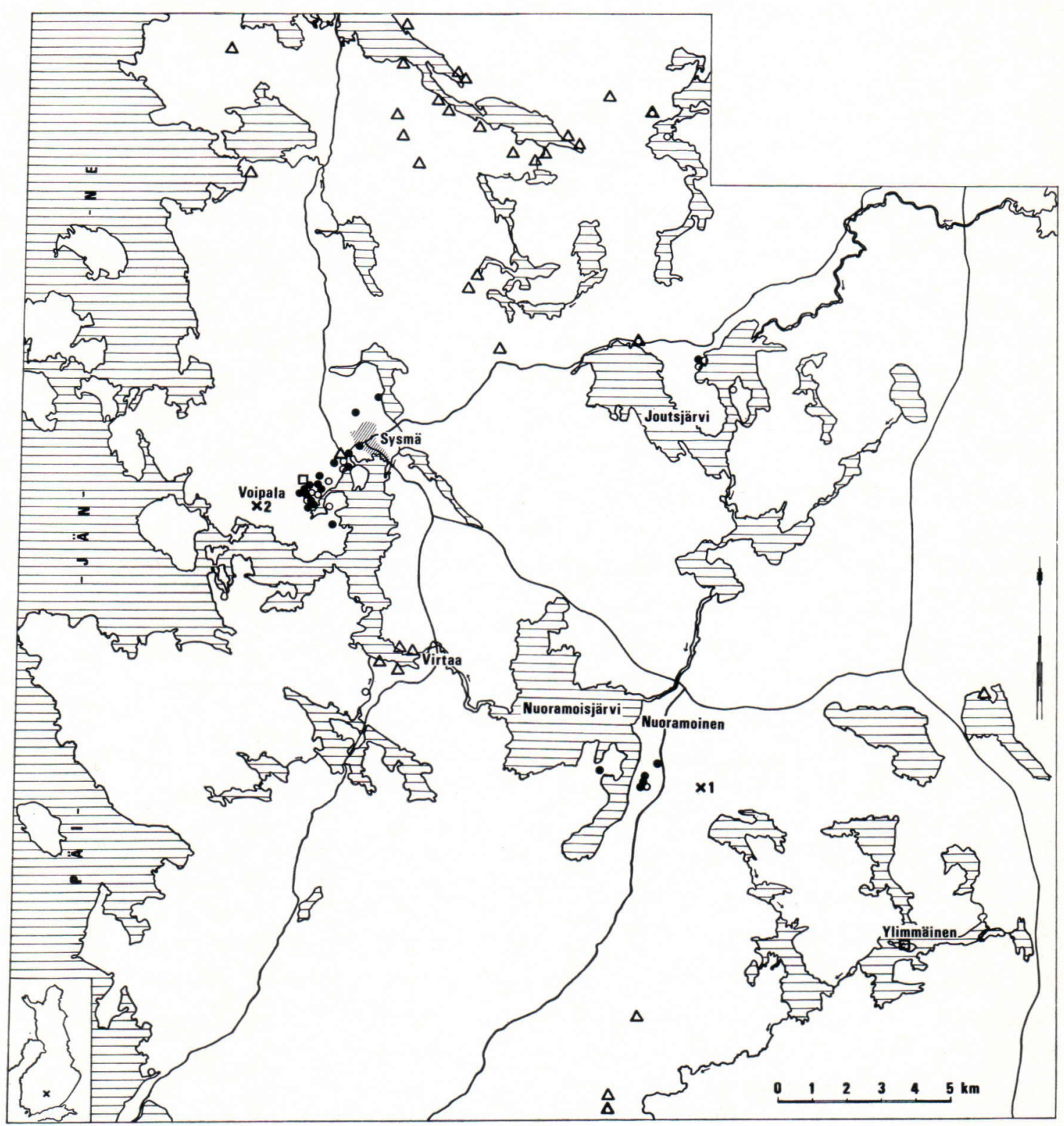

Fig. 1. Simplified map of the Sysmä area showing the localities of its archaelogical finds according to Koivunen (1965) and the two present pollen analyses:

? $=$ cup stone or cup-shaped rock surface

$\mathrm{O}=$ Iron Age dwelling site

$\triangle=$ Stone Age dwelling site

$\square=$ buried treasure from around the year 1000 $\times=$ pollen analyse sites, $1=$ Kaakotinlampi, Nuoramoinen, 2 = Taruslampi, Voipala

cores obtained represent different periods of time.

The pollen diagram for Kaakotinlampi depicts the natural development of the vegeta- tion over a span of some 9000 years, and also includes features suggestive of early neolithic cultural influence in the proportions of the species identified. The ancient Lake Päijänne 
did not extend to the height of this site. The diagram for Taruslampi, on the other hand, covers the period from the Bronze Age up to the present day, and reflects the development of the vegetation during this time and the considerable changes effected on it by the activity of man. Sedimentation appears to have continued undisturbed for the period covered by this core, although at an earlier stage the site was submerged beneath the waters of the Päijänne transgression, which extended to a height of just over $90 \mathrm{~m}$ a.s.l. in this area (Saarnisto 1971a).

\section{Main features of the settlement history of Sysmä}

Relatively little is known of Stone Age settlement in Sysmä from archaeological finds. It is not possible to date the artefacts found at the many dwelling sites in the area (Fig. 1), neither is the age of the sites determined in this connection on the basis of their location (cf. Siiriäinen 1973), but some indication can be gained from fragments of clay vessels recovered from the neighbouring parishes of Luhanka and Asikkala. That in Luhanka has been shown to represent the older form of Early Combed-ware (KaI 1; 4200-3500 B.C.; Siiriäinen 1970, 1973), and the other, in Asikkala, the older and younger forms of the typical Combed-ware style (KaII 1 and KaII $23300-3000$ B.C. and $3000-2800$ B.C.) Asbestos and textile ceramics indicative of the early Metal Age have also been found at the latter site.

There are no finds from Sysmä dating from the Bronze Age or Pre-Roman Iron Age. Information on the Iron Age population of the area has, however, been obtained from several kinds of finds associated with permanent settlement during this period (Fig. 1). Charcoal retrieved from the site at Ihananiemi about $300 \mathrm{~m}$ north of Sysmä church gave a radiocarbon date of $1580 \pm 130$ B.P. (Hel-872) or A.D. 370 (Anttila 1976). This would suggest that there was Iron Age settlement at Sysmä at earlier times than scholars had previously thought, and that this would correspond to the earliest of the burial sites found in Häme (Kivikoski 1955: 44, 1973; Salmo 1953), for instance, estimates that settlement spread into the area around the year 600; the earlier flint finds, which are estimated to date back to between the 2nd and 8th centuries A.D. (Kivikoski 1955:51), are not regarded as indicative of permanent settlement.

It is thought that the people who came to the Sysmä area in the 6th and 7 th centuries A.D. and practised agriculture there were descended from the inhabitants of the area around Lake Vanajavesi (Juvelius 1925). The permanent form of settlement has continued uninterrupted up to the present day.

\section{The material and its dating}

The material presented here was obtained from borings carried out in the early spring of 1978 using a Livingstone borer. The radiocarbon dates are from the Helsinki University Radiocarbon Dating Laboratory.

The sediments of Kaakotinlampi (Fig. 1, site 1) may be regarded as representing the whole of the Flandrian period, the stratigraphy being:

0-10 cm gyttja with a high sulphide content

$10-170 \mathrm{~cm}$ dark detritus gyttja

$170-172 \mathrm{~cm}$ sulphide gyttja

172-175 cm clay gyttja

175- cm clay

The lower sulphide gyttja horizon serves to indicate an anaerobic phase in the history of the basin and that occurring closest to the surface testifies to a disturbance in the nutrient and oxygen balance of the lake at the 


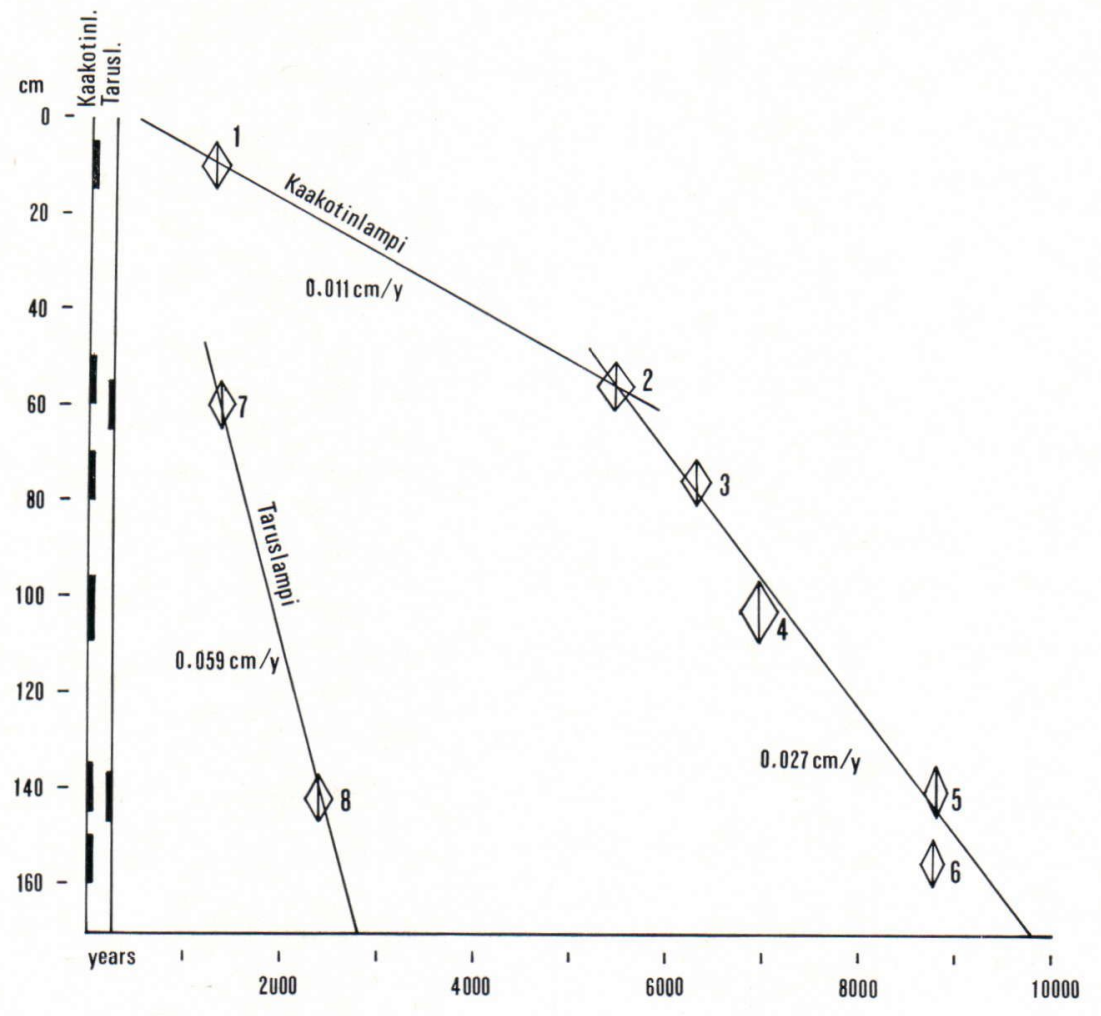

Fig. 2. Mean annual
rates of sedimentation in
the two profiles studied,
based on the pollen con-
centration values and
radiocarbon dates (Nos
$1-8)$.

most recent stage in its development (cf. Alhonen 1972, Harjula 1972, Tolonen et al. 1976, Vuorinen 1978). The latter case may well be a consequence of ditches running into Kaakotinlampi from the nearby forests. The youngest part of the profile has been omitted from the present analysis because of its extremely loose construction.

The following radiocarbon dates were obtained for the Kaakotinlampi:
The dates are indicative of a relatively even rate of sedimentation, with a mean of 0.027 $\mathrm{cm} / \mathrm{yr}$ (Fig. 2) up to around 5500 B.P. at least (about $60 \mathrm{~cm}$ level), at which point it declines abruptly to a mean of $0.011 \mathrm{~cm} / \mathrm{yr}$. The reason for this may well be connected with the discharge of the waters of the ancient Lake Päijänne via Heinolanharju around 6100 B.P. and the associated drop in the ground-water table. Kaakotinlampi is situated

Corresp. Flandrian

Subzones (Mangerud et al. 1974)
1. $5-15 \mathrm{~cm}$
Hel-1211
$1270 \pm 130$ B.P
Middle Subatlantic
2. $50-60 \mathrm{~cm}$
Hel-1212
$5470 \pm 160$ B.P.
Middle-Late Atlantic
3. $70-80 \mathrm{~cm}$
Hel-1213
$6290 \pm 160$ B.P.
Middle-Late Atlantic
4. $96-109 \mathrm{~cm}$
Hel 1214
$6940 \pm 160$ B.P.
Eearly-Middle Atlantic
5. $135-145 \mathrm{~cm}$
Hel-1215
$8790 \pm 120$ B.P.
Preboreal-Boreal
6. $150-160 \mathrm{~cm}$
Hel-1216 
within the immediate sphere of influence of the ancient Lake Päijänne, about $1 \mathrm{~km}$ from one of its bays, the present lake of Nuoramoisjärvi. A drop in the ground-water in the area by several metres would also have led to a reduction in the surface water and its rates of flow, and this would inevitably have been reflected in the lake sediments. The time discrepancy between the radiocarbon date for the level in question and the event itself is of no significance for the above theory, since the location of this sample in the profile was selected on quite separate grounds. It is also possible in theory that the slowing down in the rate of sedimentation may have taken place at a later stage, but in any case before 1270 B.P. This would seem less probable, however, in view of the magnitude of the natural event in question. A third reason for the change in rate of sedimentation could be a hiatus in the profile. Since the pollen chronology shows no evidence for this in the curves for any of the species recognized, however, the first explanation mentioned above should still be regarded as the most plausible.

The sediments sampled at Taruslampi (Fig. 1, site 2) may be estimated to represent some 3000 years of deposition (Fig. 7). The proportion of organic material, as shown by the loss-on-ignition at $+550^{\circ} \mathrm{C}$, reaches two peaks, at $145 \mathrm{~cm}(28 \%)$ and $50 \mathrm{~cm}(60 \%)$. The surface of the core $(5-0 \mathrm{~cm})$ consists of dark claygyttja with a high sulphide content, formed as a consequence of the agriculture practised in the vicinity of the basin (Alhonen 1979 and literature cited therein).

Two radiocarbon dates were obtained for the Taruslampi profile:
A preliminary diatom analysis (by M. Eronen) on the claygyttja horizon $(170-125 \mathrm{~cm})$ points to a varied flora in which the principal species are Tabellaria fenestrata, Melosira italica var. valida, Eunotia pectinalis var. ventralis and Diploneis parma. This smalllake flora allows us to conclude that the basin had already been isolated from the ancient Lake Päijänne, and also suggests relatively poor nutrient conditions in the lake.

\section{General trends in the vegetation}

The profile from Kaakotinlampi extends back to the end of the Birch P.A.Z. (Preboreal chronozone; Mangerud et al. 1974), as may be seen both from the relative peak in Betula and from the high proportion of NAP typical of this phase (Cyperaceae, Ericales, Artemisia; Fig. 4). Since the isolation of the basin from the Yoldia Sea took place during this period, the lower samples also present clear evidence of a gradation from marine to freshwater conditions. The rich NAP flora, including Cyperaceae, Artemisia, Chenopodiaceae, Galium, Rumex acetosa, R. acetosella, R. maritimus, Urtica, Umbelliferae, Cruciferae and Thalictrum (Fig. 4) belongs to the isolation phase while the high values for Gramineae pollen, with a peak at the level of $165 \mathrm{~cm}$ indicate the vegetation around the lake basin shortly before the forestation (cf. Fig. 5). This may be regarded at the same time as marking the beginning of the transition from the $\mathrm{Be}$ tula P.A.Z. to the Pinus P.A.Z. The radiocarbon date for the level $150-160 \mathrm{~cm}, 8780 \pm$ 130 B.P. is almost identical to that obtained for the corresponding horizon at Varrassuo, near Lahti (8760 \pm 260 B.P.; Donner 1966).

Both the pollen concentration and influx figures (Figs. 5 and 6) show the formation of the forests, together with the spread of
7. 55-65 cm Hel-1209
$1360 \pm 120$ B.P. Late
8. $137-147 \mathrm{~cm}$ Hel-1210 $2380 \pm 140$ B.P. Early
Subatlantic 
Kaakotinlampi, Sysmä

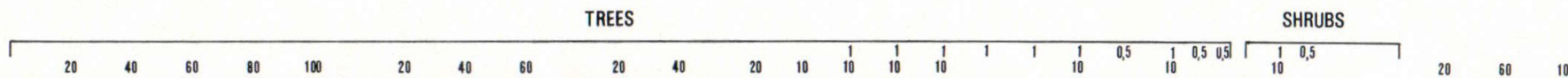

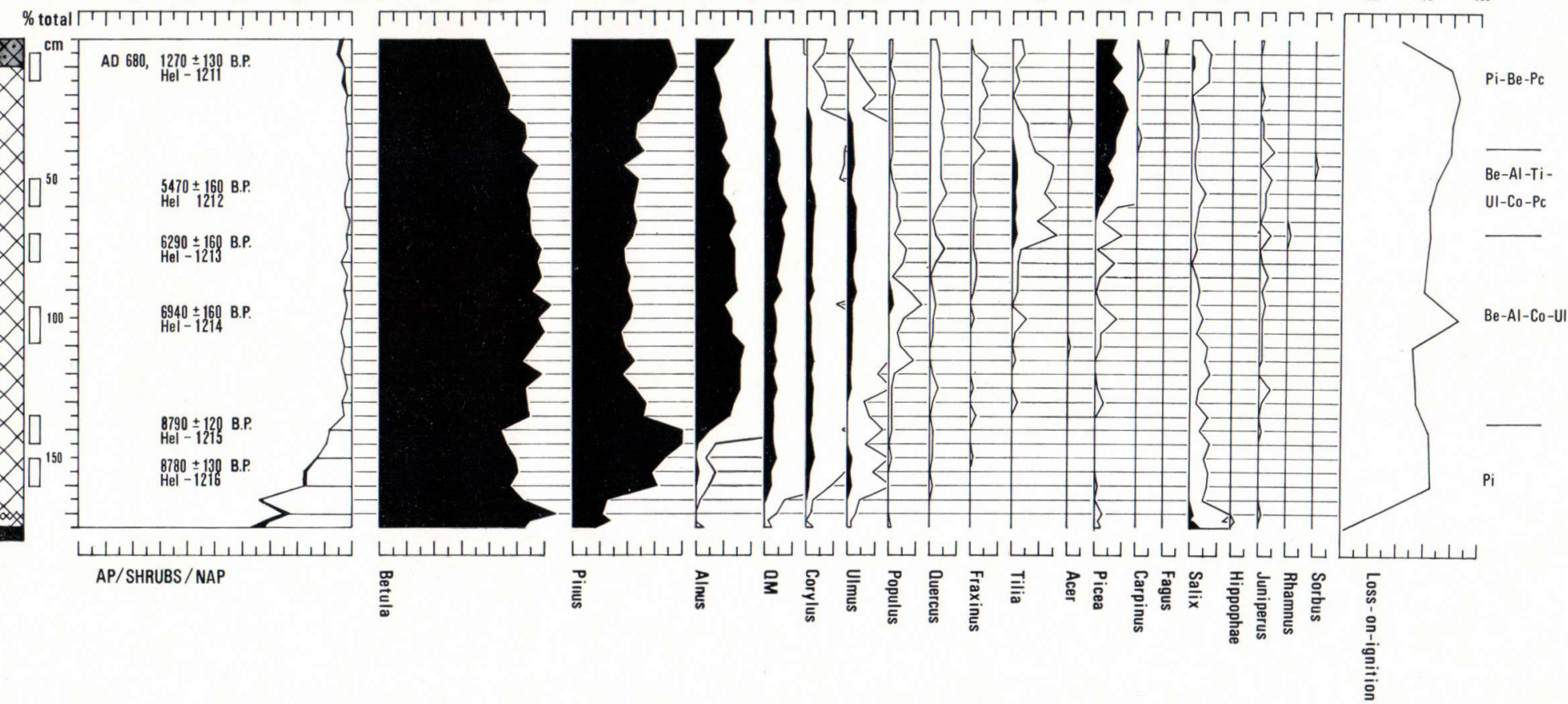

Fig. 3. Relative pollen diagram with radiocarbon dates from the lake sediments at Kaakotinlampi, showing the history of the forest cover Abbreviations: $\mathrm{Pi}=$ Pinus, $\mathrm{Be}=$ Betula, $\mathrm{Pc}=$ Picea, $\mathrm{Al}=$ Alnus, $\mathrm{Ti}=$ Tilia, $\mathrm{Ul}=$ Ulmus, $\mathrm{Co}=$ Corylus. Analyst I. Vuorela. 
Kaakotinlampi, Sysmä

POLLen CONCENTRATION

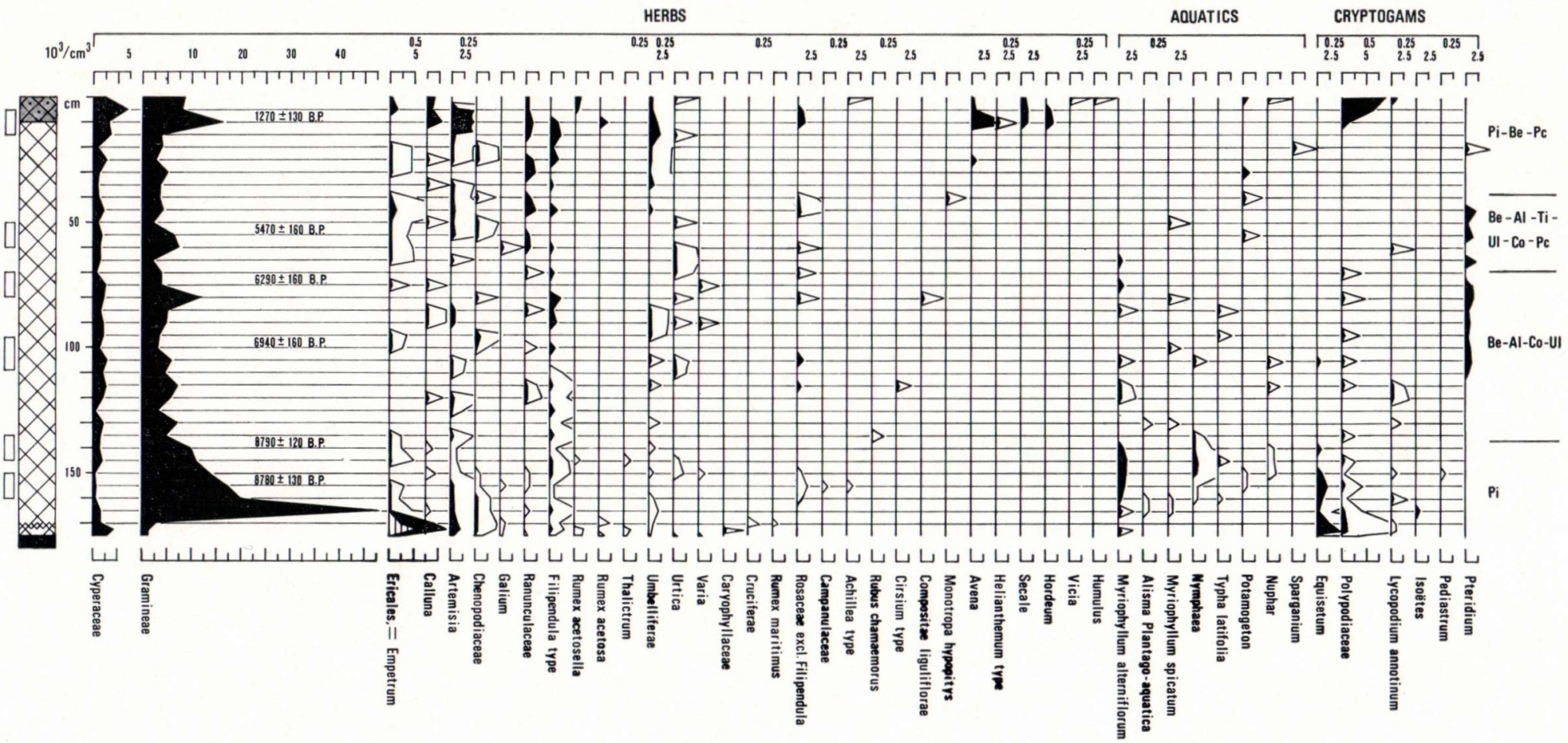

Fig. 4. Pollen concentration diagram for the NAP species at Kaakotinlampi, drawn in a stratigraphical order. Analyst I. Vuorela. 


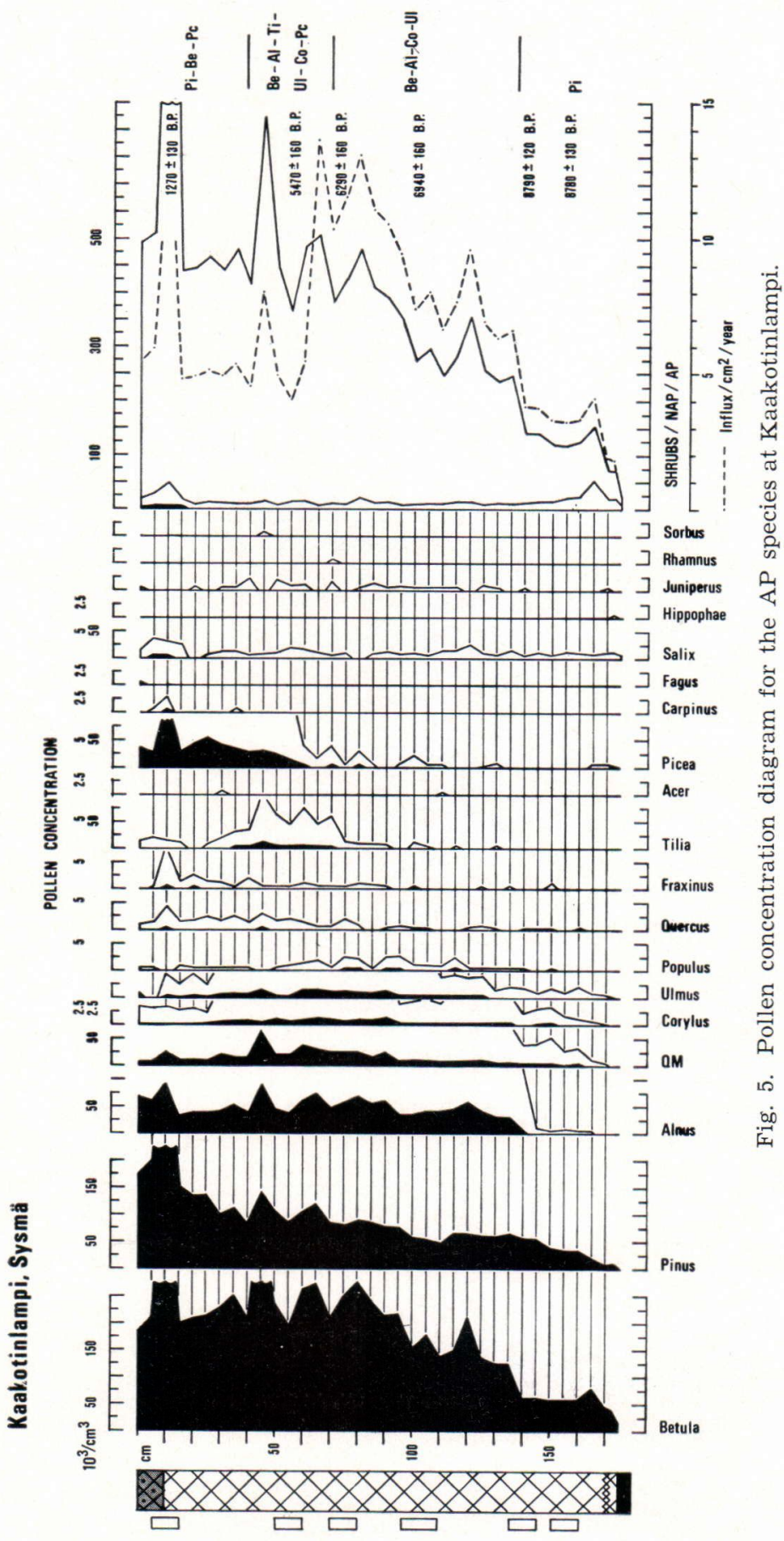

Corylus and Ulmus, in the area to have begun at the end of the Pinus P.A.Z.; the pollen concentration values (Fig. 5) increasing from a Boreal minimum of about $25000 / \mathrm{cm}^{3}$ to $125000 / \mathrm{cm}^{3}$.

The invasion horizon of Alnus ( $\mathrm{A}^{0}$ boundary) is deemed to lie at a level of $140 \mathrm{~cm}$, dated to $8790 \pm 120$ B.P. Dates of $8660 \pm 170$ (Hel-928), $8020 \pm$ (Hel-841) and $8580 \pm 170$ (Hel-827) have been obtained for the corresponding phase in Hollola, south of Lake Päijänne (Donner et al. 1978), and $7310 \pm 270 \quad$ (Hel-306) in Lammi some $30 \mathrm{~km}$ west of Lahti (Huttunen 1980).

The determination of the local vegetational subzone boundaries for the Atlantic chronozone in this case, includes special features in the case of the spread of Tilia. This species makes its appearance in the Kaakotinlampi diagram relatively late on becoming common only close to the Late-Atlantic subzone, $6290 \pm 160$ B.P. at the $70-80 \mathrm{~cm}$ level. It would seem probable from the proportions of other species, however, that this boundary must lie at the $100 \mathrm{~cm}$ level where the short-term rise in Tilia pollen is dated to $6940 \pm 160$ B.P. (cf. Donner 1966, Donner et al. 1978). The slow start of the Tilia curve could 
be connected with the eventual slight traces of land utilization discussed later.

The spread of Picea to the Sysmä area is dated to $5470 \pm 160$ B.P. corresponding to that from Asikkala, $5890 \pm 190$ (Hel-106; Saarnisto $1971 \mathrm{a}$ ), and being a good 1000 years earlier than in the area to the south of Lake Päijänne (cf. Tolonen 1978, Vuorela 1978, Huttunen 1980). The same level, $50-60 \mathrm{~cm}$, also features a relative decline in Ulmus pollen and a clear drop in its pollen influx values (Fig. 6).

The Sub-boreal/Sub-atlantic chronozone boundary may be regarded as being located at a level of approx. $37 \mathrm{~cm}$, as determined from the occurrence of Carpinus pollen (Sauramo 1958, Mangerud et al. 1974). A distinct decline in the proportion of broad-leaved deciduous (QM) trees at this point is interpreted as representing climatic deterioration.

In the uppermost part of the diagram (Pinus-BetulaPicea P.A.Z.) indicators of human activity arise sharply at $15 \mathrm{~cm}$ level including an increase in Gramineae pollen, Cereals and Humulus.

\section{Evidence of settlement in the diagrams}

On the basis of the chronology described above, the

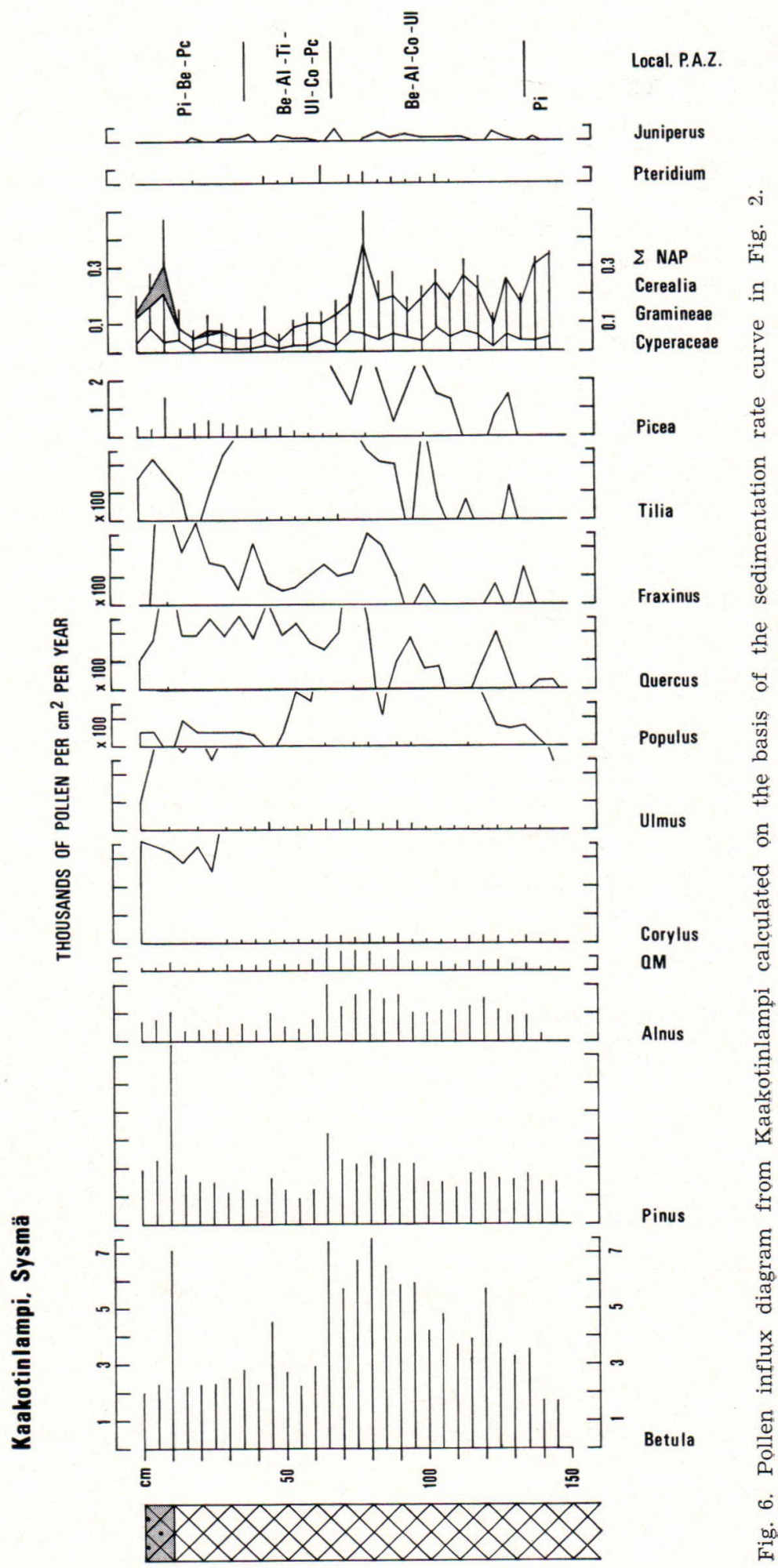


profile from Kaakotinlampi may be said to represent the time space from the Mesolithicum up to the beginning of the Viking period, while the Taruslampi diagram covers the time from the Bronze Age close to the present day. Disturbances in the vegetation brought about by human activity are reflected in the diagrams from both sites, the earliest cultural indicators at Kaakotinlampi being found in a sequence between 60 and $110 \mathrm{~cm}$ corresponding to the boundary between the Pre-ceramic and Ceramic periods approx. $7000-5500$ B.P. This interval in time is characterized in the diagram (Fig. 4) by the relatively plentiful occurrence of Pteridium spores, a feature common to many diagrams from the area to the south of Lake Päijänne in connection with this period (Huttunen and Tolonen 1977, Donner et al. 1978, Tolonen 1978, Vuorela 1978), and one which has been interpreted as an indicator of forest fires (Oinonen 1967). The fires have at least in part been attributed to the effects of human activity with grazing and other forms of human influence extending the duration of reforestation. In view of the very early stage in cultural development referred to here, it may well be that this feature at least at its earliest phase reflects periodic burning over in order to improve the conditions for various animals hunted by the local population for food rather than the effects of grazing (Siiriäinen, personal communication 1980). Later at 80 cm level the Gramineae peak together with an increasing number of Pteridium spores could indicate an even more developed stage of grazing.

Other features encountered at this period in the Kaakotinlampi diagram include a relative increase in the nitrophilous Urtica, the dwarf shrubs (Ericales), Populus, Juniperus and large amounts of Gramineae pollen at times. Chenopodiaceae and Artemisia occur only intermittently during this 'Pteridium phase', and thus do not as such serve to in- dicate permanent settlement in the area. The same thing can be said about the absence of Plantago major and Rumex pollen. The wide fluctuations found in the amounts of Gramineae and Betula pollen, together with the simultaneous high values for Juniperus, lend further support to the interpretation of the nature of human activity on the area set out above.

The uppermost part of the diagram represents the beginning of cultivation at Sysmä, and is dated here to $1270 \pm 130$ B.P., that is the 7th century A.D., the Merovingian period. The interval of time preceding this, i.e. the Bronze and Iron Age, is extremely poor in cultural indicators in this diagram, while the increase in the proportion of Picea pollen similarly suggests that the area remained practically in its natural state.

The period preceding cultivation and the changes in the vegetation brought about by the commencement of agriculture in the area are depicted even more clearly in the Taruslampi diagrams (Figs. 7-9), and since the radiocarbon date for the level of $137-147$ $\mathrm{cm}$ refers precisely to the transition from the Bronze Age to the Iron Age, this supplies a firm basis for examining the markers of human activity. The archaelogical conclusions reported above do not point to any Bronze Age settlement at Sysmä, nor does the Kaakotinlampi diagram contain any cultural indicators from that period. Nevertheless, the Taruslampi diagram is by no means so clearcut in this matter, as the lowermost samples certainly contain features which would suggest that some grazing took place in that area during the period in question. In the case of the AP this evidence chiefly takes the form of low figures for spruce pollen, and this is accompanied by increased proportions of Juniperus and Polypodiaceae and relatively large amounts of Gramineae. There are few actual cultural indicators, however, and those that do appear are rather sporadic (e.g. Rumex 


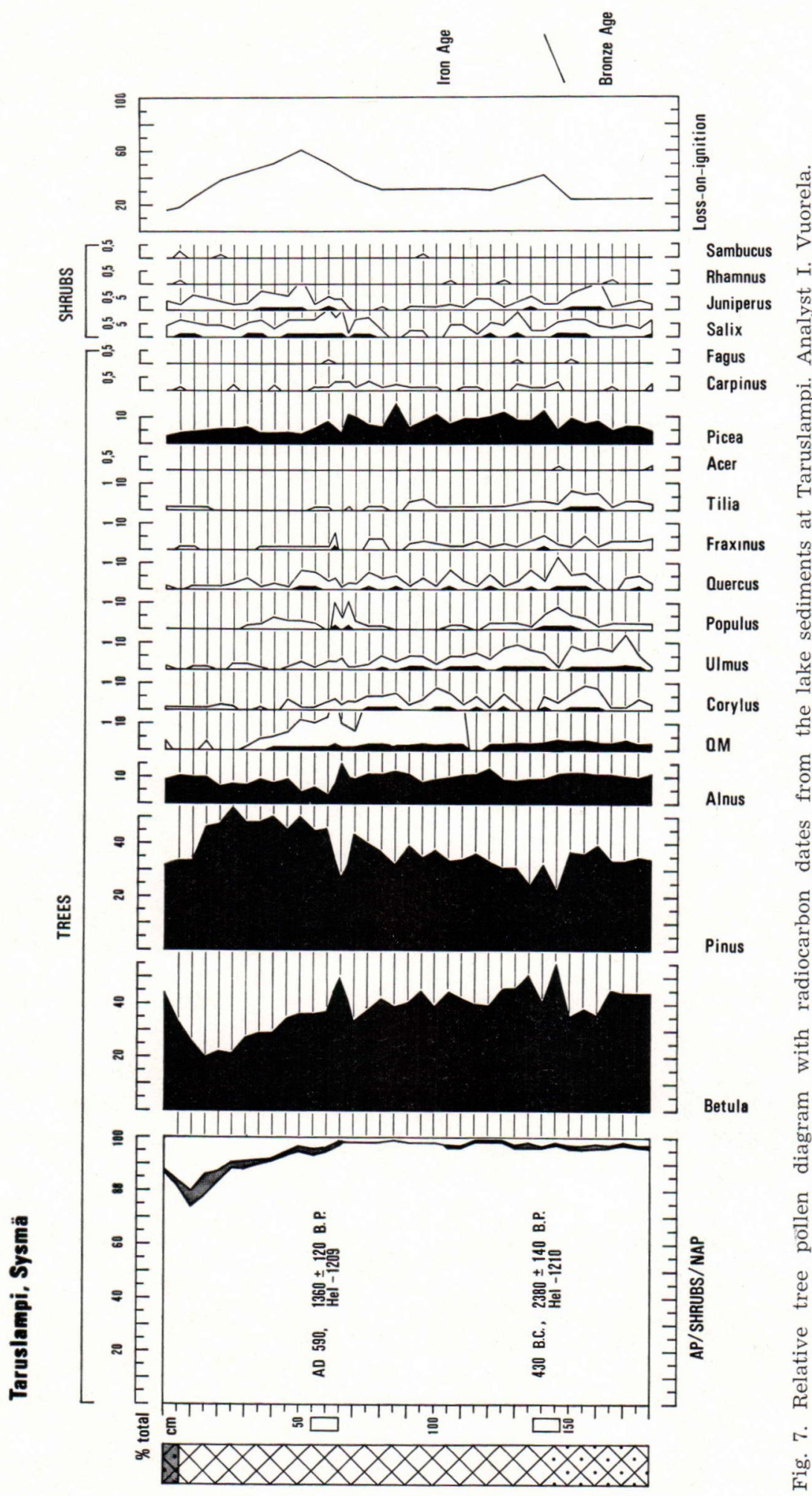




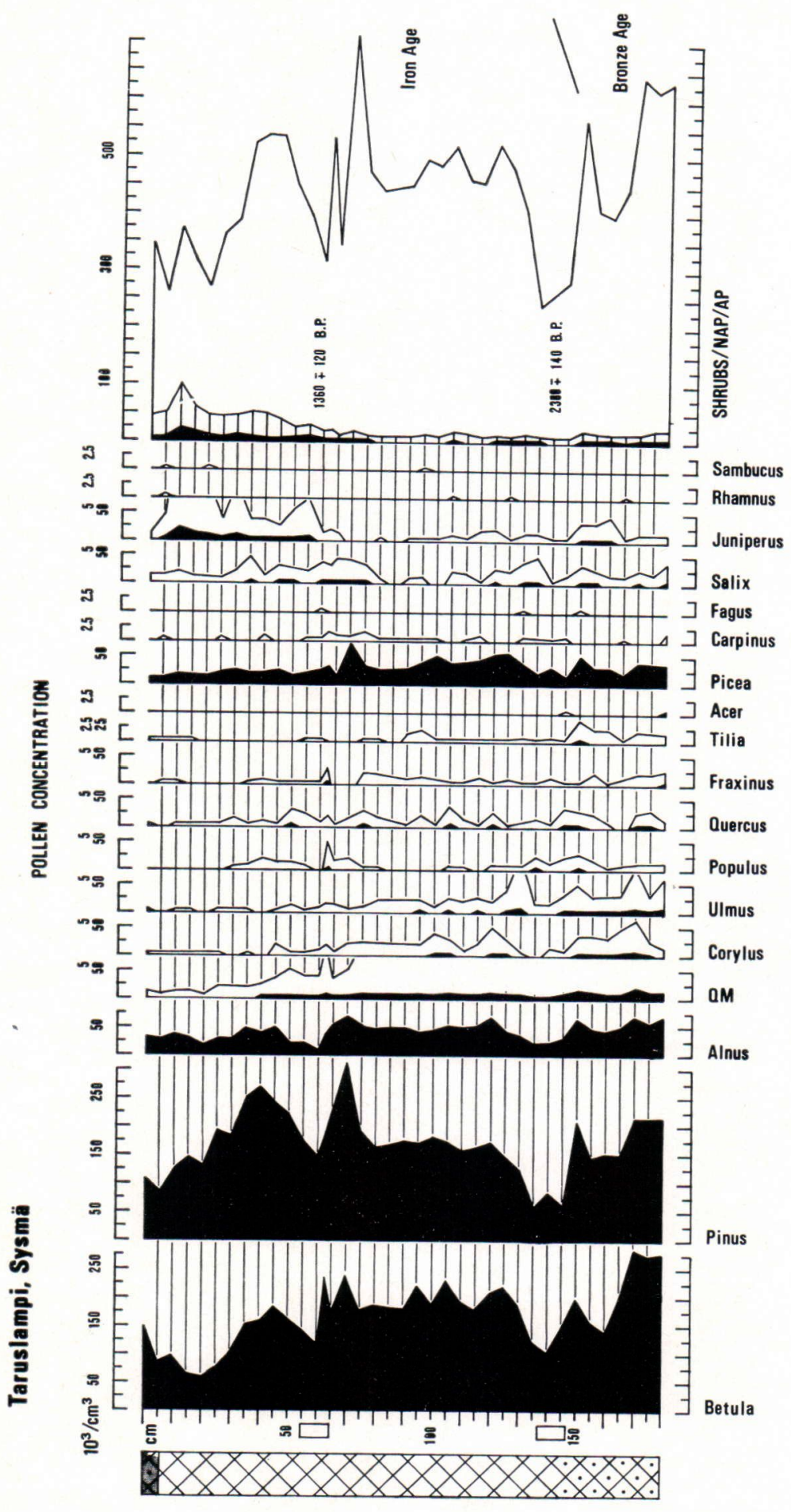

acetosella). These features may be comparable with the Early Metal Age finds at Asikkala.

The cultural indicators continue to decline in the sediments corresponding to the Iron Age, increasing again only at the $60 \mathrm{~cm}$ level with the commencement of : permanent settlement. The date obtained for this well defined event, $1360 \pm 120$ B.P., corresponds well with the result from Kaakotinlampi. The doubling in the range of NAP species at this point is accompanied by many times greater amounts of pollen of many of those species which had occurred earlier (Fig. 9), in particular the pollen of Gramineae, Rumex, Umbelliferae, Filipendula, Chenopodiaceae and Ericales. Pollen of the cereals also make their appearance at the $60 \mathrm{~cm}$ level. This is preceded in the diagram by a stage in which disturbances are seen within total AP, a feature linked with forest clearance, and with the ensuing changes in growing conditions. The improved illumination adjacent to the areas of clearance will stimulate flowering, and the effects of reforestation will be reflected in the typical pioneer species. The abrupt decline in the proportion and concentration of Alnus pollen in particular is an indication 
of a rapid transition from 'slash and burn' techniques to field cultivation in the surroundings of Taruslampi.

A certain periodicity may be detected in the pollen concentration figures for the cultural indicators in the upper $60 \mathrm{~cm}$ of the diagram (Fig. 9). Since no such variations are seen in the AP concentrations (Fig. 8), this obviously arises from changes in the intensity of cultivation over this period of some 1000 years. It may be established that agriculture has been practised in Sysmä continuously from Merovingian times, as may be seen not only from the curves for individual indicator species, but also in the steady decline in loss-onignition values (Fig. 7), pointing to the effects of field erosion.

\section{Conclusion}

The present preagricultural pollen indicators are of special interest as it has not proved possible to date the Stone Age dwelling sites in the Sysmä area by the artefacts found at them. Among these are the indicators of forest fires together with evidence of delayed reforestation in the diagram of Kaakotinlampi dated to approx. 5000-7000 B.P. The profile from Taruslampi

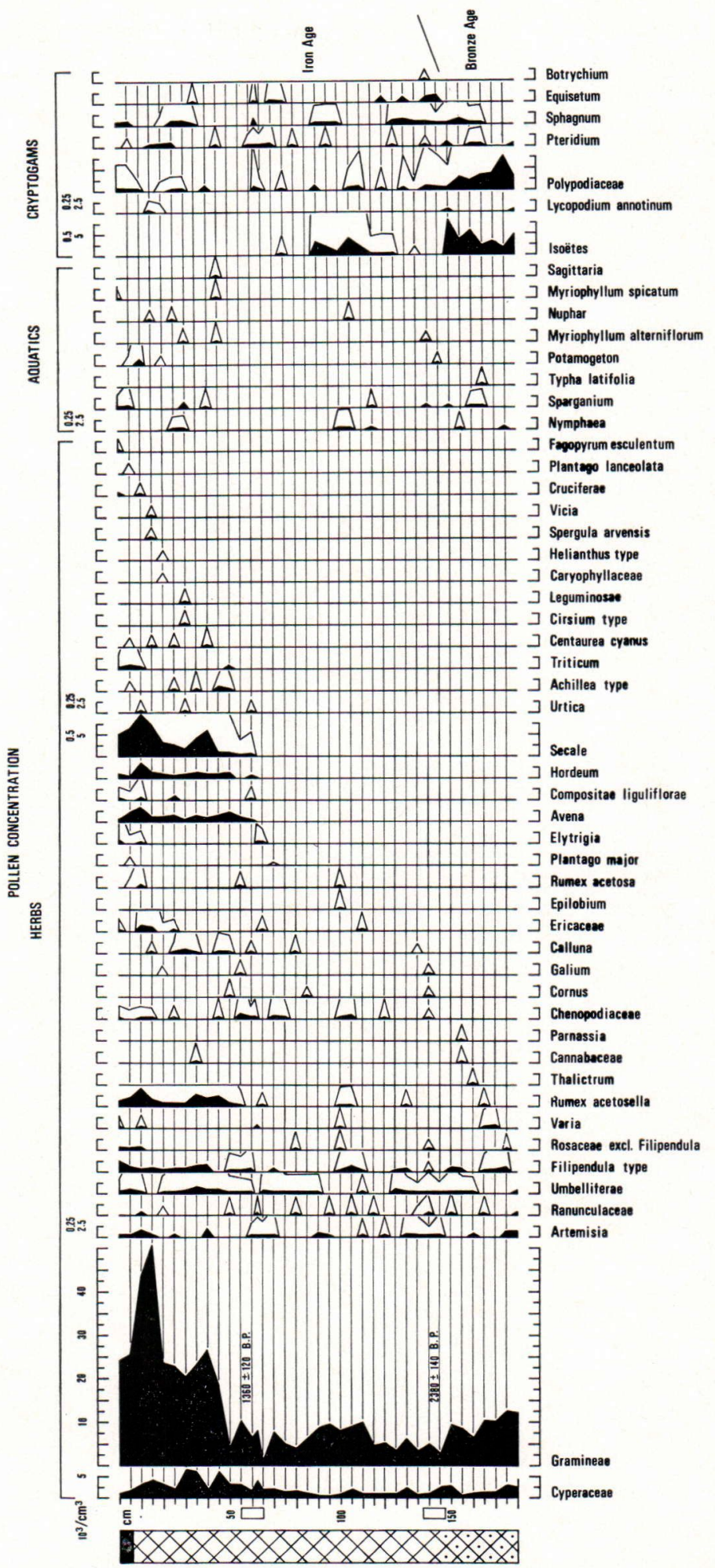


suggests that this area at least was affected by some form of human activity during the Bronze Age. This settlement may, however, be assumed to have been based largely on hunting and grazing.

The present radiocarbon dates lend support to the theory that the current settlement in the Sysmä area originated from a migration of population from the surroundings of Lake Vanajavesi some time before A.D. 700 (cf. Juvelius 1925, Kivikoski 1955). The commencement of field cultivation at Hattula has been dated to around A.D. 570 (Vuorela 1975), although sporadic signs of earlier agriculture are also to be seen, and a corresponding date

\section{References}

Aario, L. (1936) Entwicklung des südlichen VorPäijännesees. Fennia 62 (1): 1-62.

Aario, R. (1965) Development of ancient Lake Päijänne and the history of the surrounding forests. Ann. Acad. Scient. Fennicae A III 81: $191 \mathrm{pp}$.

Alhonen, P. (1972) Gallträsket: The geological development and palaeolimnology of a small polluted lake in Southern Finland. Soc. Scient. Fennica, Comm. Biol. 57: 1-34.

- (1979) The sedimentary record of the cultural eutrophication and pollution of lakes in Finland. Arch. Hydrobiol. 86: 13-26.

Anttila K. (1976) Excavation report, manuscript in the topographical archives of the Museum Office, Helsinki.

Donner, J. (1966) The Late-glacial and early Postglacial pollen stratigraphy of southern and eastern Finland. Soc. Scient. Fennica Comm. Biol. 29 (3): 1-24.

Donner, J., Alhonen, P., Eronen, M., Jungner, $H$. and Vuorela, I. (1978) Biostratigraphy and radiocarbon dating of the Holocene lake sediments of Työtjärvi and the peats in the adjoining bog Varrassuo west of Lahti in southern Finland. Ann. Bot. Fennici 15: 258-280.

Eronen, M. and Matiskainen, H. (1979) Luonnonolosuhteiden kehitys etelä-Päijänteellä ja Vesijärven ympäristössä jääkauden lopusta nykyaikaan. Lahden museo- ja taidelautakunta. Tutkimuksia 14: $1-23$. of approx. A.D. 650 is given for the parish of Koski (Tolonen 1978). The present work yields dates of A.D. 590 and 680. The transition from 'slash and burn' cultivation to more advanced field cultivation is reflected in the increase in indicator pollen and in the rise in the proportion of mineral material in the sediment.

Acknowledgements - The author is grateful to Dr. Matti Eronen and Dr. Hannu Hyvärinen for their help in the field work and to Mr. Malcolm Hicks for the English translation of the manuscript. She also wants to thank Dr. Sheila Hicks for the critical comments on the manuscript.
Harjula, H. (1972) Hiidenveden ja Tuusulanjärven rehevöitymisen kehitys pohjasedimenttien valossa. Helsingin Kaupungin Vesilaitos. Mimeographed report, $109 \mathrm{pp}$.

Huttunen, P. (1980) Early land use, especially the slash- and -burn cultivation in the commune of Lammi, southern Finland, interpreted mainly using pollen and charcoal analyses. Acta Bot. Fennica 113: 1-45.

Huttunen, P. and Tolonen, M. (1977) Human influence in the history of Lake Lovojärvi, S. Finland. Finskt Museum 1975: 68-117.

Juvelius, E. W. (1925) Sysmän pitäjän historia. 732 pp. Lahti.

Kivikoski, E. (1955) Hämeen historia I, Hämeen rautakausi, 197 pp. Hämeenlinna.

- (1973) Die Eisenzeit Finnlands, Bildwerk und Text. Finnische Altertumsgesellschaft, $150 \mathrm{pp}$ and 146 tables. Helsinki.

Koivunen, P. (1965) Inventory report for Sysmä, manuscript in the topographical archives of the Museum Office, Helsinki.

Mangerud, J., Andersen, S. T., Berglund, B. E. and Donner, J. J. (1974) Quaternary statigraphy of Norden, a proposal for terminology and classification. Boreas 3: 109-128.

Oinonen, E. (1967) Sporal regeneration of bracken (Pteridium aquilinum (L.) Kuhn. in Finland and in the light of the dimensions and the age of its clones. Acta Forest. Fennica 83 (1): $1-96$. 
Saarnisto, M. (1971a) The upper limit of the Flandrian transgression of Lake Päijänne. Soc. Scient. Fennica Comm. Physico-Math. 41: 149170.

- (1971b) The history of Finnish lakes and Lake Ladoga. Soc. Scient. Fennica Comm. PhysicoMath. 41: 371-388.

Salmo, H. (1953) En karelsk silverskatt från Sysmä socken. Finskt Museum 1953: 13, 19.

Sauramo, M. (1958) Die Geschichte der Ostsee. Ann. Acad. Sci. Fennicae A III 51: 522 pp.

Siiriäinen, A. (1969) Über die Chronologie der steinzeitlichen Küstenwohnplätze Finnlands im Lichte der Uferverschiebung. Suomen Museo 1969: 40-73.

- (1970) Archaeological background of ancient Lake Päijänne and geological dating of the meso-neolithic boundary in Finland. Bull. Geol. Soc. Finland 42: 119-127.

- (1973) Studies relating to shore displacement and stone age chronology in Finland. Finskt Museum 1973: 1-22.

Tolonen, K., Tolonen, M., Honkasalo, L., Lehto- vaara, A., Sorsa, K. and Sundberg, K. (1976) Esihistoriallisen ja historiallisen maankäytön vaikutuksesta Lammin Lampellonjärven kehitykseen (Summary: The influence of prehistoric and historic land use of Lake Lampellonjärvi, South Finland). Luonnon Tutkija 80: 1-15.

Tolonen, M. (1978) Palaeoecology of annually laminated sediments in Lake Ahvenainen, S. Finland. I. Pollen and charcoal analyses and their relation to human impact. Ann. Bot. Fennici 15 (3): $177-208$.

Tolvanen, V. (1922) Der Alt-Päijänne. Morphologische Studie. Fennia 43: 1-49.

Vuorela, I. (1975) Pollen analysis as a means of tracing settlement history in SW Finland. Acta Bot. Fennica 104: 1-48.

- (1978) Local settlement history of the Lahti area as shown by pollen analysis. Bull. Geol. Soc. Finland 50: 45-57.

Vuorinen, J. (1978) The influence of prior land use on the sediments of a small lake. Pol. Arch. Hydrobiol. 25 (1/2): 443-451.

Manuscript received, December 10, 1980 